\title{
PENGARUH PEMBERIAN JUS MENTIMUN TERHADAP TEKANAN DARAH LANSIA DENGAN HIPERTENSI DI PSTW SINTA RANGKANG TAHUN 2020
}

\author{
Meirlina Christine $^{1}$, Theresia Ivana ${ }^{2}$, Margareta Martini ${ }^{3}$ \\ ${ }^{123}$ Sekolah Tinggi Ilmu Kesehatan Suaka Insan Banjarmasin \\ Imeirlina6@gmail.com²theresiaivana84@gmail.com
}

\begin{abstract}
Hypertension is a major problem disease in society, especially for the elderly. The cucumber juice (jus mentimun) is one of non-pharmacology technic to reduce high blood pressure, because it contains hypotensive properties. Out from 56 person in PSTW Sinta Rangkang, 17 participants have hypertension without comorbidities. Purpose of this study was to study the effectiveness of cucumber juice to lower the blood pressure of the elderly with hypertension. Design of this study was preexperimental design with pre and post-test for one group test through 17 participants that meet the sample requirements. Data analysis using Wilcoxon Rank test showed differences in blood pressure (systolic and diastolic) before and after administration of cucumber juice $(\alpha=0.002)$. This study showed that cucumber juice was effective to lower the blood pressure of participants.
\end{abstract}

Keywords: cucumber juice, elderly, hypertension

\section{Abstrak}

Hipertensi adalah penyakit utama di masyarakat, salah satunya lansia. Jus mentimun adalah salah satu teknik non-farmakologi untuk menurunkan tekanan darah karena memunyai sifat hipotensif. Terdapat 17 orang penderita hipertensi tanpa penyakit penyerta dari 56 orang di PSTW Sinta Rangkang. Penelitian dilakukan untuk mengetahui pengaruh jus mentimun untuk menurunkan tekanan darah lansia dengan hipertensi. Desain penelitian pre-eksperimen dengan satu grup tes kepada 17 orang responden yang memenuhi syarat sampel. Data analisis menggunakan Wilcoxon Rank Test menunjukkan perbedaan tekanan darah (sistole dan diastole) sebelum dan sesuai pemberian jus mentimun $(\alpha=0,002)$. Hal ini menunjukkan bahwa jus mentimun efektif terhadap penurunan tekanan darah.

Kata kunci: hipertensi, jus mentimun, lansia

\section{Latar belakang}

Hipertensi merupakan penyakit yang menjadi masalah utama di masyarakat terutama lansia yang merupakan penyakit degeneratif. Hipertensi memiliki bebagi resiko komplikasi, apa lagi terkait dengan masalah degeneratif. Mentimun merupakan salah satu jenis buah yang mudah ditemukan dan sering dikonsumsi oleh masyarakat dan dapat menurunkan tekanan darah (Prakorso, 2014).

Hipertensi atau tekanan darah tinggi adalah suatu kondisi dimana tekanan darah seseorang berada diatas angka normal yaitu 120/80 mmHg (Susilo \& Wulandari, 2011). WHO menyatakan batas tekanan darah adalah 120-140 mmHg dan tekanan sistole 80$90 \mathrm{mmHg}$. Penyakit hipertensi in sering dijumpai di masyarakan maju, baik pria maupun wanita, tua ataupun muda dan gejalanya tidak nampak dengan jelas. Penyakit ini disebut sebagai silent diseases dan merupakan faktor resiko utama perkembangan atau penyebab penyakit jantung dan stoke. Bila tidak terkontrol akan menyebabkan kerusakan pada organ tubuh lainnya, seperti otak, ginjal, dan mata dan kelumpuhan organ-organ gerak (Ridwan, 2009).

Angka kejadian hipertensi di dunia cukup tinggi, menurut data WHO tahun 2010 dari $50 \%$ penderita hipertensi yang diketahui hanya 255 mendapatkan pengobatan, dan hanya $12,5 \%$ yang diobati dengan baik. Tahun 2011 di Indonesia banyaknya penderita hipertensi diperkirakan 15 juta orang dewasa dan lansia, tetapi hanya $4 \%$ yang merupakan hipertensi terkontrol. Prevalensi 6-15\% pada orang dewasa, $50 \%$ diantaranya tidak menyadari sebagai penderita hipertensi sehingga mereka cenderung untuk menjadi hipertensi berat karena tidak mengetahui faktor resikonya, dan $90 \%$ merupakan hipertensi esensial (Prakoso dkk, 2014). Data penderita 10 kasus penyakit terbanyak di Kalimantan Tengah tahun 
2016, hipertensi merupakan kasus penyakit nomor 2 tertinggi terdapat 41.819 kasus (kalteng.bps.go.id).

Penyakit tekanan darah tinggi/hipertensi merupakan salah satu faktor resiko terpenting yang dapat mengakibatkan penyakit cerebrovaskuler, gagal jantung congestive, stroke, penyakit jantung koroner dan penyakit ginjal yang memiliki angka morbiditas dan mortalitas tinggi (Wulandari, 2011). Bagi orang yang sudah menderita hipertensi, pengobatan dapat menggunakan terapi disamping efek samping yang ditimbulkan rendah dibandingkan pengobatan secara klinis. Tindakan pencegahan baik yang belum pernah menderita hipertensi ataupun bagi yang belum pernah terkena hipertensi yaitu dengan perubahan gaya hidup menjadi gaya hidup sehat. Gaya hidup sehat ini antara lain meliputi pola makan, aktivitas dan olahraga. Dalam gaya hidup sehat yang utama adalah makanan yang kita konsumsi serta diperbanyak mengkonsumsi sayur dan buah-buahan (Muhammadun, 2010).

Cara untuk menurunkan tekanan darah adalah dengan metode farmakologi (menggunakan obat) dan non farmakologis (tanpa obat) (Myrank, 2009). Obat anti hipertensi telah lama terbukti efektif digunakan untuk mengontrol tekanan darah, akan tetapi sumber daya nabati juga memiliki peranan penting dan dapat dimanfaatkan dalam mengontol tekanan darah. Sumber daya yang dapat dimanfaatkan untuk mengontrol tekanan darah antara lain buah-buahan, sayur-sayuran yang tinggi serat, kaya vitamin serta mineral (Wulandari, 2011). Salah satu buah yang dapat dimanfaatkan untuk menekan dan menstabilkan tekanan darah adalah mentimun. Mentimun merupakan sayuran yang mudah didapat dan harganya pun murah. Dikalangan masyarakat umum, mentimun sudah lazim dikonsumsi untuk sekedar pelengkap hidangan, ini bisa dijadikan solusi untuk mengobati hipertensi secara nonfarmakologis (Kusnul \& Munir, 2011).

Beberapa jenis buah dan sayuran yang berkhasiat menurunkan tekanan darah tinggi antara lain seledri, ketimun, labu siam, selada air, lobak, tomat, belimbing wuluh, belimbing manis, semangka, wortel, pisang, apel, dan kiwi (Mangonting, 2008). Dari berbagai buah-buahan ini, kandungan pada mentimun yang mampu membantu menurunkan tekanan darah, karena mentimun mengandung kalium (potassium), magnesium, dan fosfor yang efektif mengobati hipertensi. Mentimun yang bersifat diuretik karena kandungan airnya yang tinggi sehingga membantu menurunkan tekanan darah (Dewi.S \& Familia.D, 2010).

Buah mentimun mempunyai sifat hipotensif (menurunkan tekanan darah), karena kandungan air dan kalium dalam mentimun akan menarik natrium kedalam intraseluler dan bekerja dengan membuka pembulu darah (vasodilatasi) yang dapat menurunkan tekanan darah (Beevers, 2007). Kalium merupakan elektrolit intraseluler yang utama, dalam kenyataannya $98 \%$ kalium tubuh berada dalam sel, $2 \%$ ini untuk fungsi neuromuskuler. Kalium mempengaruhi aktivitas baik otot skeletal maupun otot jantung (Brunner \& Suddarth, 2014).

Dari hasil studi pendahuluan yang dilakukan oleh peneliti pada tanggal 24-25 Maret 2020 di PSTW Sinta Rangkang, hasil wawancara dari 3 lansia dan data dari klinik kesehatan di dapat data jumlah lansia di PSTW Sinta Rangkang berjumlah 56 orang, pasien yang menderita hipertensi sebanyak 19 orang, ada 2 lansia yang menderita penyakit lain yaitu stroke dan demensia berat, dan 17 lansia tidak ada penyakit lain yang menyertai.

Latar belakang dan studi pendahuluan yang sudah dipaparkan ini membuat peneliti tertarik untuk meneliti seberapa besar pengaruh turunnya tekanan darah dengan mengonsumsi mentimun. Penelitian ini bertujuan mengidentifikasi penurunan tekanan darah yang ditimbulkan dengan pemberian jus mentimun.

\section{Metode Penelitian}

Penelitian ini mengunakan rancangan praeksperimental dengan rancangan pra-pasca tes dalam satu kelompok (one-grup pra-posttest design) dengan ciri penelitian ini adalah mengungkapkan hubungan sebab akibat dengan cara melibatkan satu kelompok subjek

Variabel dalam penelitian ini adalah variabel bebas dan variabel terikat. Variabel bebas penelitian adalah konsumsi jus mentimun. Variabel terikat adalah penurunan tekanan darah. Populasi pada penelitian ini berjumlah 19 orang lansia dengan hipertensi di PSTW Sinta Rangkang. Sampel dalam penelitian ini 
Jurnal Keperawatan Suaka Insan (JKSI) Vol. 6, No. 1, Juni 2021

adalah lansia dengan hipertensi berjumlah 17 orang dengan teknik sampling yang digunakan adalah purposive sampling. Kriteria pemilihan sampel yaitu: lansia dengan hipertensi tanpa penyakit penyerta, lansia dengan hipertensi grade 1 dan 2 dan bersedia menjadi sampel penelitian.

Penelitian ini dilakukan di PSTW Sinta Rangkang. Waktu pelaksanaan penelitian ini dilakukan selama 7 hari mulai dari 11 November sampai dengan 17 November 2020. Instrumen yang di gunakan dalam penelitian ini adalah lembar observasi, yang digunakan untuk mencatat hasil pengukuran tekanan darah sebelum dan sesudah pemberian jus mentimun.

Analisis data menggunakan analisis univariat dengan menggunakan tabel distribusi dan frekuensi dan analisis bivariat menggunakan Wilcoxon Rank Test, untuk mengetahui pengaruh jus mentimun terhadap penurunan tekanan darah.

\section{Hasil Penelitian}

Tabel 1. Distribusi Frekuensi Karakteristik Responden berdasarkan Usia dan Jenis Kelamin di PSTW Sinta Rangkang, 2020.

\begin{tabular}{llcc}
\hline No. & \multicolumn{1}{c}{ Umur } & F & \% \\
\hline 1. & Lansia awal (46-55 tahun) & 0 & 0 \\
2. & $\begin{array}{l}\text { Lansia akhir (56-65 } \\
\text { tahun) }\end{array}$ & 4 & 23,5 \\
M. & 13 & 76,5 \\
& \multicolumn{1}{c}{ Manula (> 65 tahun) } \\
\hline \multicolumn{1}{c}{ Jumlah } & 17 & 100 \\
\hline No & Jenis Kelamin & F & $\%$ \\
\hline 1 & Laki-laki & 7 & $41.2 \%$ \\
\hline 2 & Perempuan & 10 & $58.8 \%$ \\
\hline & $\quad$ Jumlah & 17 & $100 \%$ \\
\hline
\end{tabular}

Tabel 1 menggambarkan distribusi frekuensi responden dilihat dari usia dan jenis kelamin. Sebagian besar usia responden adalah manula (> 65 tahun) sebanyak 13 responden (76,5\%) sedangkan paling sedikit adalah lansia akhir (56-65 tahun) sebanyak 4 orang $(23,5 \%)$. Pengambilan klasifikasi umur dalam penelitian ini berdasarkan Depkes RI (2009) yaitu lansia awal (46-55 tahun), lansia akhir (56-65 tahun), manula (>65 tahun). Selanjutnya, terdapat perbedaan proporsi jenis kelamin responden. Jenis kelamin responden perempuan lebih banyak yaitu 10 responden $(58,8 \%)$ dibandingkan dengan responden laki-laki yaitu 7 responden $(41,2 \%)$.

Selanjutnya, hasil pengukuran tekanan darah sebelum diberikan terapi jus mentimun. Hasil pengukuran dapat dilihat melalui tabel 2 di bawah ini.

Tabel 2. Tekanan darah sebelum diberikan terapi jus mentimun di Panti Sosial Tersna Werdha Sinta Rangkang.

\begin{tabular}{lcc}
\hline & \multicolumn{2}{c}{ TD Pre Pemberian Jus } \\
& \multicolumn{2}{c}{ Mentimun } \\
\cline { 2 - 3 } No & Sistole & Diastole \\
\hline 1 & 150 & 100 \\
2 & 140 & 90 \\
3 & 160 & 100 \\
4 & 140 & 100 \\
5 & 160 & 100 \\
6 & 140 & 80 \\
7 & 160 & 100 \\
8 & 150 & 100 \\
9 & 140 & 80 \\
10 & 150 & 80 \\
11 & 160 & 100 \\
12 & 160 & 90 \\
13 & 160 & 90 \\
14 & 160 & 100 \\
15 & 140 & 90 \\
16 & 140 & 60 \\
17 & 160 & 100 \\
\hline
\end{tabular}

Pada tabel 2 dapat dilihat hasil pengukuran tekanan darah sebelum diberikan terapi jus mentimun, yang mana pre di ambil pada pemberian pertama dan post pada pemberian terakhir. Rata-rata tekanan darah sistole $150 \mathrm{mmHg}$ dan diastole rata-rata $91,7 \mathrm{mmHg}$.

Selanjutnya adalah hasil pengukuran tekanan darah setelah pemberian jus mentimun. Hasil pengukuran ini dapat dilihat pada tabel 3 . 
Jurnal Keperawatan Suaka Insan (JKSI) Vol. 6, No. 1, Juni 2021

Tabel 3. Tekanan darah setelah diberikan terapi jus mentimun di PSTW Sinta Rangkang.

\begin{tabular}{lcc}
\hline & \multicolumn{2}{c}{$\begin{array}{c}\text { TD Post Pemberian Jus } \\
\text { Mentimun }\end{array}$} \\
\cline { 2 - 3 } No. & S & D \\
\hline 1 & 120 & 80 \\
2 & 120 & 80 \\
3 & 120 & 80 \\
4 & 120 & 80 \\
5 & 120 & 80 \\
6 & 120 & 80 \\
7 & 130 & 90 \\
8 & 120 & 80 \\
9 & 120 & 80 \\
10 & 110 & 80 \\
11 & 130 & 80 \\
12 & 120 & 80 \\
13 & 140 & 60 \\
14 & 140 & 70 \\
15 & 120 & 80 \\
16 & 140 & 80 \\
17 & 130 & 80 \\
\hline
\end{tabular}

Pada tabel 3 menunjukkan hasil tekanan darah sesudah diberikan terapi jus mentimun yang diambil pada pemberian terakhir. Rata-rata tekanan darah pada sistole $124,7 \mathrm{mmHg}$ dan diastole $78,8 \mathrm{mmHg}$.

Tabel 4. Analisis Selisih Tekanan darah Sistole dan Diastole sebelum dan sesudah diberikan terapi jus mentimun di PSTW Sinta Rangkang.

\begin{tabular}{ll}
\hline & Selisih Sistole dan Diastole \\
\hline $\mathrm{Z}$ & -3.038 \\
Asymp.Sig.(2-tailed) & 0.002 \\
\hline
\end{tabular}

Tabel 4 menunjukkan hasil analisis perbedaan tekanan darah systole dan diastole untuk pemberian jus mentimun sebelum dan sesudah pemberian jus mentimun pada responden. Hasil uji Wilcoxon Rank Test menunjukkan adanya perbedaan pada tekanan darah (systole dan diastole) responden sebelum dan sesudah pemberian jus mentimun $(\mathrm{p}=0.002)$.
Selanjutnya, pemberian jus mentimun memberikan efek menurunkan tekanan darah $(\mathrm{z}=-3.038)$ responden.

\section{Pembahasan}

Penyakit hipertensi bisa terjadi pada segala usia, tetapi paling sering menyerang orang dewasa yang berusia 35 tahun atau lebih serta lansia. Hal ini disebabkan adanya perubahan alami pada jantung, pembuluh darah dan hormon. Namun, jika perubahan ini disertai dengan faktor resiko maka dapat memicu terjadinya hipertensi (Brunner \& Suddarth, 2014).

Penurunan tekanan darah terjadi karena mentimun mempunyai kandungan kalium yang menyebabkan penghambatan pada Sistem Renin Angiotensin juga menyebabkan terjadinya penurunan sekresi aldosteron, sehingga terjadi penurunan reabsorpsi natrium dan air di tubulus ginjal. Akibat dari mekanisme tersebut, maka terjadi peningkatan diuresis yang menyebabkan berkurangnya volume darah, sehingga tekanan darah pun menjadi turun.

Penelitian Aisyah (2014) menyebutkan mentimun memiliki berbagai macam kandungan gizi diantaranya adalah kalium, kalsium, dan magnesium. Berbagai penelitian membuktikan bahwa ada kaitan erat antara intake kalium, kalsium, dan magnesium terhadap penurunan tekanan darah. Semakin rendah intake kalium maka tekanan darah akan semakin tinggi. Rasio natrium/kalium juga berhubungan dengan tekanan darah. Pengurangan intake natrium sebesar $100 \mathrm{mmol}$ perhari dan konsumsi kalium sampai dengan 70 mmol dalam sehari, maka tekanan darah sistole diprediksi akan turun sebesar 3,4 mmHg. Intake kalium berpengaruh pada pembuluh darah yaitu kalium akan menurunkan resistensi pembuluh darah perifer yang secara langsung dapat melebarkan arteri, peningkatan pengeluaran air dan natrium dari tubuh, penekanan sekresi reninangiotensin, dan stimulasi dari aktivitas pompa natrium-kalium.

Fungsi dari kalium adalah pemeliharaan keseimbangan cairan dan elektrolit serta keseimbangan asam basa. Bersama kalsium, kalium berperan dalam transmisi saraf dan relaksasi otot. Di dalam sel, kalium berfungsi sebagai katalisator dalam 
banyak reaksi biologik, terutama dalam metabolisme energi dan sintesis glikogen dan protein (Nurhidayat, 2012).

Mentimun bersifat diuretik karena kandungan airnya yang tinggi sehingga membantu menurunkan tekanan darah. Unsur fosfor, asam folat dan vitamin $\mathrm{C}$ pada mentimun bermanfaat menghilangkan ketegangan atau stres (Wijaya, 2000). Ini membuktikan bahwa meskipun hipertensi, tekanan darahnya dapat diturunkan dengan terapi nonfarmakologis jus mentimun yang mengandung zat-zat yang membantu tekanan darah turun mencapai normal.

Hasil penelitian ini menunjukkan perbedaan proporsi berdasarkan distribusi frekuensi perubahan tekanan darah sistole sebelum diberikan terapi jus mentimun, yang dapat dilihat pada tabel 2 dan 3 . Kedua tabel ini menunjukkan terjadi penurunan tekanan darah pada partisipan sebanyak 16 orang $(94,1 \%)$, yang terjadi penaikan tekanan darah sebanyak 1 orang $(5,9 \%)$ dan yang tidak mengalami perubahan sebanyak $0(0 \%)$. Selanjutnya, terdapat perbedaan proporsi berdasarkan distribusi frekuensi perubahan tekanan darah diastole sebelum diberikan terapi jus mentimun. Penelitian ini menunjukkan terjadinya penurunan tekanan darah sebanyak 13 partisipan $(76,5 \%)$, yang terjadi penaikan tekanan darah sebanyak 1 orang $(5,9 \%)$ dan yang tidak mengalami perubahan sebanyak 3 orang $(17,6 \%)$. Hasil penelitian ini didukung oleh penelitian yang dilakukan oleh Aisyah (2014) yang menunjukkan penurunan tekanan darah diastole sebesar $6.67+$ $6.726 \mathrm{mmHg}$.

Hasil Wilcoxon Rank Test untuk melihat efektifitas dari pemberian jus mentimun pada responden dengan $\alpha=0,025$; hasil penelitian ini $\alpha=0,000$. Jika hasil $\alpha$ di bawah 0,025 maka Ha di terima, yang berarti terjadi perubahan tekanan darah sistole sesudah diberikan terapi jus mentimun.

Meningkatnya tekanan darah seiring dengan bertambahnya usia memang sangat wajar. Hal ini disebabkan adanya perubahan alami pada jantung, pembuluh darah, dan hormon. Penelitian yang dilakukan oleh Rahma Elya (2015) menguatkan hipotesis ini, yang menunjukkan ada pengaruh penurunan tekanan darah pada lansia dengan penangan non-farmakologis yaitu dengan pemberian jus mentimun. Terdapat perbedaan tekanan darah pada penderita hipertensi sebelum dan sesudah mengosumsi jus mentimun.

\section{Kesimpulan}

Analisis tekanan darah sebelum diberikan terapi jus mentimun yang mana pre di ambil pada pemberian pertama dimana rata-rata tekanan darah pada saat pre dengan sistole rata-rata 150 dan diastole rata-rata 91,7. Analisis tekanan darah sesudah diberikan terapi jus mentimun yang mana post di ambil pada pemberian terakhir dengan rata-rata tekanan darah pada post sistole rata-rata 124,7 dan diastole 78,8 $\mathrm{mmHg}$.

Hasil uji Wilcoxon Rank Test, untuk melihat efektifitas dari pemberian jus mentimun pada responden analisis perubahan selisih tekanan darah sistole dan diastole sebelum dan sesudah di berikan terapi jus mentimun di PSTW Sinta Rangkang dengan $\alpha=0,025$; hasil dari penelitian ini $\alpha=0,002$. Jika hasil $\alpha$ di bawah 0,025 maka ada perubahan tekanan darah sebelum dan sesudah di berikan jus mentimun. Terdapat efektifitas jus mentimun terhadap penurunan tekanan darah pada lansia di PSTW Sinta Rangkang.

\section{Acknowledgement}

Terima kasih kepada PSTW Sinta Rangkang dan STIKES Suaka Insan yang sudah memfasilitasi pelaksanaan kegiatan penelitian ini.

\section{Daftar Pustaka}

AA, H. (2009). Metode Penelitian Keperawatan dan Tehnik Analisis Data. Jakarta: Salemba Medika.

Ahmad, Z. F. (2017). Pengaruh Pemberian Jus Mentimun (Cucumis Sativus Linn) Terhadap Tekanan Darah Pada Penderita Hipertensi Usia Dewasa.

A. Aisyah, \& E. Probosari, 2014. Pengaruh Pemberian Jus Mentimun (Cucumis Sativus L) terhadap Penurunan Tekanan Darah pada Penderita Hipertensi Wanita Usia 40-60 tahun. Journal of Nutrition College, vol. 3, no. 4, pp. 818-823, Oct. 2014. https://doi.org/10.14710/jnc.v3i4.6885

Amin, A. R. (2015). Mengenal Budidaya Mentimun Melalui Pemanfaatan Media Informasi. JUPITER Vol. XIV No. 1. 
Jurnal Keperawatan Suaka Insan (JKSI) Vol. 6, No. 1, Juni 2021

ArgoMedia, R. (2009). Solusi sehat mengatasi Hipertensi . Jakata : PT. Argomedia Pustaka .

Baradero, M. (2008). Seri Asuhan Keperawatan Klien Dengan Gangngguan Cardiovaskular. Jakarta : EGC.

Brunner \& Suddarth.(2014). Keperawatan MedikalBedah. Edisi 12. Jakarta: Penerbit Buku Kedokteran: EGC

Corwin, E. (2000). Buku Saku Patofisiologi. Jakarta : EGC.

Dewi, S. R. (2014). Buku Ajar Keperawatan Gerontik. Yogyakarta: Deepublish.

Dewi, S \& Familia, D (2010). Hidup Bahagia dengan Hipertensi. Yogyakarta: A Plus

Elya, Rahma. Hermawan, Dessy. Trismiana, Eka. ( 2015). Pengaruh Jus Mentimun (Cucumis Sativus) terhadap Penurunan Tekanan Darah pada Penderita Hipertensi di UPTD Panti Sosial Lanjut Usia Tresna Wedha Kecamatan Natar Kabupaten Lampung Selatan Tahun 2015. file://C:/Users/ACER/AppData/Local/Temp/229 -417-1-SM.pdf

Hidayat, A. A. (2008). Riset Keperawatan Dan Teknik Penulisan Ilmiah Edisi 3. Jakarta: Salemba medika.

Kemenkes, R. (2018). Hasil Utama Riset Kesehatan Dasar. 2018: Balitbang Kemenkes RI.

Khasanah, N. (2012). Waspada Beragam Penyakit Degeneratif Akibat Pola Makan. Jakarta: Laksana.

Kusnul, Z \& Munir, Z (2011). Efek Pemberian Jus Mentimun terhadap Penurunan Tekanan Darah file:///C:/Users/ACER/AppData/Local/Temp/6161-1-PB.pdf

Lebalado, L.P \& Mulyati, Tatik. (2014). Pengaruh Pemberian Jus Mentimun (Cucumis Sativus L.) terhadap Tekanan Darah Sistolee dan Diastoleik pada Penderita Hipertensi. https://media.neliti.com/media/publications/1850 56-ID-none.pdf

Mangonting, D. et al. 2008. Tanaman Lalap Berkhasiat Obat. Jakarta: Penerbit Penebar Swadaya

Manuntung, A. (2018). Terapi Perilaku Kognitif Pada Pasien Hipertensi. Malang: Penerbit Wineka Media.

Maryam, R. S., Ekasari, M. F., \& dkk. (2008). Mengenal Usia Lanjut dan Perawatannya. Jakarta: Salemba Medika.
Muhammadun, A.S (2010). Hidup Bersama Hipertensi. Yogyakarta: In Books

Muhith, A., \& Siyoto, S. (2016). Pendidikan Kperawatan Gerontik. Yogyakarta: CV Andi Offset.

Muttaqin, A. (2009). Pengantar Asuhan Keperawatan Klien dengan Gangguan Sistem Kardiovaskular. Jakarta : Salemba Medika .

Notoadmodjo, S. (2010). Prosedur Penelitian Kesehatan. Jakarta: Rineka Cipta.

Nurhidayat, S. (2012). Efektivitas Jus Mentimun Terhadap Penurunan Tekanan Darah Tinggi Pada Penderita Hipertens. Ponorogo: Muhamadiyah University of ponorogo Press.

Nursalam. (2016). Metodologi Penelitian Ilmu Keperawatan Pendekatan Praktis. Jakarta: Salemba Medika .

Olivia, F. (2013). Awet Muda ala Korea. Jakarta : PT Gramedia .

Prakoso, A. (2014). Prosiding Konferensi Nasional II PPNI Jawa Tengah. Pengaruh Pemberian Jus Mentimun Terhadap Tekanan Darah pada Lansia dengan Hipertensi di Posyandu di Kabupaten Demak.

Ridwan (2009) Mencegah, Mengenal, Mengatasi Silent Killer Hipertensi. Semarang: Pustaka Widyana

Rukmana, I. R. (1995). Budidaya Mentimun. Yogyakarta : Kanisius.

Sugiyono. (2008). Metode Kualitatif Dan Kuantitatif. Bandung: Alfabeta.

Susilo, Y \& Wulandari, A. (2011). Cara Jitu Mengatasi

Hipertensi. Yogyakarta. Andi

Tambayong, J. (2000). patofisiologi untuk keperawatan. Jakarta: EGC.

Tjokroprawiro, A. (2015). Buku Ajar Ilmu Penyakit Dalam Fakultas Kedokteran Universitas Airlangga Rumah Sakit Pendidikan Dr. Soetomo surabaya edisi 2. Surabaya: Airlangga University Press.

Wahdah, N. (2011). Menaklukan Hipertensi dan Diabetes. Yogyakarta: Multipres.

Wijaya.(2000) Kandungan Buah Mentimun bagi Tubuh. Yogyakarta: Grha Ilmu

Wulandari, A. (2011). Cara Jitu Mengatasi Hipertensi. Yogyakarta: CV. Andi Offset. 